By DOROTHY H. LITCHFIELD

\title{
Departmental and Divisional
}

\section{Libraries'}

$\mathrm{D}^{\mathrm{B}}$ PARTMENTAL LIBRARIES had been chosen by the chairman as the subject for discussion. The four speakers represented universities with divergent points of view, since one of the libraries has ten departmental units and one has none at all. Stephen A. McCarthy, assistant director of libraries, University of Nebraska, led off with an informal account of recent developments at $\mathrm{Ne}$ braska. Their departmental libraries in all subjects except chemistry, architecture, and geology will be in the new main building. Features now up for consideration are personnel; cataloging and filing; special services, such as routing the current periodicals to faculty members.

Ilse Wilhelmi, supervisor of departmental libraries at Ohio State University, followed with a paper entitled "My Departmental Libraries Want to Know." Here, as everywhere, cataloging problems are of special concern. In one of the scientific libraries, analytic cards for the Journal of Agricultural Research articles had been filed in the catalog some time before the faculty requested that the cards be withdrawn. Freshmen had objected to the inclusion of cards for articles they couldn't understand. Happily, an-

1 Report of the University Libraries Section meeting at Chicago on December 28, I940. Chairman Earl N. Manchester presided; Dollie B. Hepburn, supervisor, acquisition department, Columbia Univer sity Library, substituted for Dorothy H. Litchfield as secretary. other scientific library had already asked for these same cards; so the transfer was made to everyone's satisfaction.

The speaker touched on classification and subject headings; filing; ordering of L.C. cards; uniform circulation rules; return of little-used volumes to the main library; opportunity for departmental librarians to attend staff meetings in the main library. The difficulty of acquiring reference technique is illustrated by the story of the zealous custodian who filed a pink slip in the catalog for every question answered by the main library staff. After a time, her catalog cards were lost in between wads of pink slips. Miss Wilhelmi epitomized the whole departmental point of view when she said that a faculty member wants the same kind of service a business firm expects of its special library.

Next, Fred Folmer, supervisor of departmental libraries at the University of Iowa, described a centralized system in his paper "Are We One or Eleven?" Since Iowa acquired a supervisor of departmental libraries sixteen years ago, the library has been able to reduce the number of departmental units from 2 I to IO. There are well-formulated relationships with each department of the main library; order ; cataloging ; serials ; documents ; reference; circulation; binding; reserves; library instruction. In observing these relationships, the custodian must maintain a 
delicate balance in loyalties between the department he serves and his colleagues in the main library. No one has yet found a way to arrange staff meetings of departmental libraries, which everyone agrees would be beneficial.

\section{Dr. Van Hoesen's Paper}

The last paper, by Dr. Van Hoesen, librarian, Brown University, was read by William $H$. Jesse, superintendent of circulation. At Brown, eighteen departmental libraries were recently absorbed into the main library or one of the two divisional libraries outside the main building. A divisional library includes material in several related subjects of a group, such as the physical sciences. It is advisable that no department or division be established unless it is organized as an administrative unit, with certain minimum requirements such as a full-time assistant and library hours approximately those of the main library.

The nucleus of many a departmental library is the privately owned faculty member's collection, which he keeps in his office and plans to turn over to the library some day. But the nature of its origin ought not to justify continuation of a departmental library along lines incompatible with the general library policy of the university.

\section{Discussion}

MR. GEORGE B. BROWN, assistant order department, University of Illinois. About the question of duplicating catalog cards for departmental libraries. We have heard that Nebraska and Ohio State type all duplicate cards. At Illinois we bought a multigraphing machine for $\$ 1600.00$ We make no attempt to send copies of one department's cards to a related department.

MR. RALPH H. PARKER, director of li- braries, University of Georgia. In connection with our present project of completely reclassifying the departmental libraries, we have set up an automatic system of sending to every department a complete set of cards for every book purchased in its field, whether or not the book is shelved there.

MR. EDWARD A. HENRY, director of libraries, University of Cincinnati. It seems to me that there is a staggering amount of revision going on in the libraries where there is no duplicating machine.

MR. JAMES A. MCMILLEN, director of libraries, University of Louisiana. We installed a Seto-type machine for printing cards. Cost $\$$ I 700.00 .

MISS HELEN DAWLEY, serial cataloger, University of Chicago. At Chicago we have just discarded our Seto-type for a new kind of machine.

MISS EVELYN M. HENSEL, catalog librarian, Pennsylvania State College. It has been found indispensable to have sets of cards for related books regardless of their location. For example, the physics and chemistry libraries interchange cards; the agriculture library has a complete set of cards for every book on forestry.

miss wilhelmi. $\mathrm{H}$ as the University of Nebraska had any success with circulating current periodicals to the faculty? We tried it in our law library, with discouraging results.

Mr. mCCARThy. The departmental librarian arranges this with the secretary of the department, who takes entire charge of it.

MR. THOMAS P. FLEMING, librarian, Medical School, Columbia University. It is managed the same way in our school.

MR. RALPH E. ELLSWORTH, director of libraries, University of Colorado. Don't we spend too much time talking about the practical problems instead of the educational side of departmental libraries? Let us consider the intangible ideas involved.

MR. FLEMING. I agree. We ought to spend less time worrying about the loss of a current 
periodical and more time trying to let the faculty know about articles in those periodicals that they might not come across themselves.

MR. LLOYD W. JOSSELYN, reference librarian, Purdue University. Nobody has mentioned the problem of special collections which are kept locked up. One library has keys to forty-seven separate collections ... it would be better if everything were in open stacks.

Chairman. Yes. The different points of view expressed here today show us the importance of open stacks ... and open minds.

\section{Departmental Librarians' Problems}

The proceedings and transactions of this meeting bring a touch of nostalgia to one who was a departmental librarian in the late nineteen twenties. The problems of fifteen years ago are still unsolved: personnel ; cataloging; binding; responsibility for equipment and housing; allocation of funds; correlation of reference service with the main library. Even the departmental library's right to existence is still challenged-and effectually-by some of the university libraries today, although the practice now established of appointing a director of libraries suggests that the departmental idea is accepted by an increasing number of presidents and trustees.

The most conspicuous advance in departmental practice seems to have been made in cataloging. Departments are receiving full sets of cards and analytics, even when the main library has the master set; while duplicating machines rush the cards through without the old time-consuming revision. Some cataloging departments are even supplying cards for related books shelved elsewhere in the system. One main library tried to speed up its output of departmental cards by cutting down on the collation, imprint, and notes; but this was firmly opposed by any departmental librarian with enough professional training to know just how useful the complete bibliographical information could be.

\section{Professional Training versus Subject Knowledge}

The question of professional training versus subject knowledge is still disputed vigorously in departmental circles. In effect, should the librarian of a physics library be a librarian or a physicist? The main library staff prefers a professional librarian who will respect the principles of library economy; and the physics department holds out for someone who speaks its language.

Several of the speakers touched on the departmental reactions to the main library policies of acquisition and binding. Has the departmental librarian a right to change binders because he has found one who will do the work at a third less, in spite of the fact that the head of the binding department knows that particular binder's work is poor? Why, asks the faculty chairman of his departmental library committee, does the main library place the periodical subscriptions through a certain European agent, when there is an American agent who charges much less?

Although the departmental librarian often finds himself able to marshal main library opinion in his support, he sometimes must conduct his own campaign for equipment and stack space. The head of a scientific laboratory is loath to spend hard-won apparatus money on catalog trays, and he would rather buy anything than a new stack unit for the library. One speaker told of stopping all new books 
and periodicals to a departmental library, with the explanation that there simply wasn't any more shelving space. In two weeks the required expansion was provided.

Gradually, by methods running the gamut of persuasion all the way from presidential ukase to subterfuge, univer- sity librarians are taking over the departmental libraries. Library schools are working toward the day when they will develop departmental librarians who are specialists in the subject itself as well as in its bibliography. It is a goal worth striving for, although in this feverish age it seems impossible of attainment.

\section{A Handbook of Medical Library Practice}

A HANDBOOK OF MEDICAL LIBRARY PRACTICE is in preparation by a committee of the Medical Library Association. Based on a preliminary manuscript by $M$. Irene Jones of the medical science department, Detroit Public Library, this book will be the result of the combined efforts of a group of medical librarians who are trying here to collect and present in orderly fashion those differences in material and procedures which distinguish a medical library from a general one. Their intention is to give chiefly the added information a general librarian needs upon entering the medical field. Far from being a complete manual of procedure, the volume presupposes some general knowledge of library methods and tools. It will form, as its title indicates, a supplementary handbook of special practices and reference equipment for medicine.

Particularly full treatment will be given subject headings, classification, reference books, rare books, and the history of medicine. The contents will comprise the following chapters: I. The medical library and the librarian, by Judith Wallen Hunt; II. Selection and ordering of books and periodicals, by Bertha B. Hallam; III. Cataloging, by L. Margueriete Prime; IV. Subject headings, by Isabelle T. Anderson; V. Classification, by Mary Louise Marshall and M. Irene Jones; VI. Reference, by Eileen R. Cunningham; VII. Pamphlets, pictures, microfilm, etc., by Eleanor Fair and Lillia M. D. Trask with the collaboration of Ethel Wigmore; VIII. Rare books and the history of medicine, by Chauncey D. Leake and Gertrude L. Annan.

This editorial committee, under the chairmanship of Janet Doe, hopes for publication in the spring of I94I. Inquiries may be addressed to the secretary of the association, Anna C. Holt, 25 Shattuck St., Boston. 